\title{
SYNTHESIS AND ${ }^{1}$ H-NMR OF DEUTERIUM LABELED D,L-HOMOSERINE LACTONE HYDROCHLORIDES
}

\author{
Kondareddiar Ramalingam and Ronald W. Woodard* \\ Department of Medicinal Chemistry \\ College of Pharmacy \\ The University of Michigan \\ Ann Arbor, Michigan 48109-1065
}

\begin{abstract}
SUMMARY
The synthesis of six regiospecific deuterated $D$, L-homoserine lactone hydrochlorides from the appropriately deuterated 2-bromo-1-(tetrahydropyranyloxy) ethanes which were obtained by reduction of the corresponding ethyl bromoacetates are described. The proton $\mathrm{nmr}$ of each lactone is recorded and the chemical shift and coupling constants are reported.
\end{abstract}

Key Words : Deuterium labeling, ${ }^{1} \mathrm{H}-\mathrm{nm}$, homoserine lactone

\section{INTRODUCTION}

L-Homoserine (2-amino-4-hydroxybutanoic acid) is a pivotal amino acid utilized in a variety of pyridoxal-phosphate-dependent enzymatic reactions. (1) These enzyme reactions convert L-homoserine derivatives such as $O$ - acetyl-L-homoserine, $O$ phosphoryl-L-homoserine, and (or) $\mathrm{O}$-succinyl-L-homoserine into L-methionine (2), Lthreonine (3), and L-cystathionine (4), respectively. In order to study the mechanism of these enzymatic transformations, it is necessary to prepare regio- and stereospecifically deuterated homoserine derivatives and to assign both the chemical shifts and coupling constants of the hydrogens in the ${ }^{1} \mathrm{H}-\mathrm{nm} r$ spectra of homoserine. Since the lactone ring form of homoserine is more stable than the open-chain form and the proton chemical shifts in the five-membered ring are more distinct than in the openchain form (5), we chose the lactone ring system as our synthetic target. The deuterated homoserine lactone- $\mathrm{HCl}$ salts shown in Scheme 2 were synthesized and their ${ }^{1} \mathrm{H}-\mathrm{nm}$ spectra were recorded (see Table 1).

"To whom correspondence should be addressed. 


\section{RESULTS AND DISCUSSION}

The necessary 2-bromo-1-(2'-tetrahydropyranyloxy)ethanes were obtained by, reduction of the appropriately labeled ethyl bromoacetates with either $\mathrm{LiAlH}_{4}$ or $\mathrm{LiAID}_{4}$ (6) and $\mathrm{AlCl}_{3}$, followed by reaction with dihydropyran (7) (see Scheme 1).

$\mathrm{BrCX} \mathrm{CO}_{2} \mathrm{C}_{2} \mathrm{H}_{5}+\mathrm{LiAlY} \stackrel{\mathrm{AlCl}_{3}}{\longrightarrow} \mathrm{BrCX}_{2} \mathrm{CY}_{2} \mathrm{OH}$

1

$\mathrm{a} X=\mathrm{H}$

$\underline{b} X=H$

$c X=2 \mathrm{H}$

$d X=2 H$
2

$a Y=H$

b $Y=2 \mathrm{H}$

$\varepsilon Y=H$

d $Y={ }^{2} H$ $\underline{3}$

$\mathrm{a} X=\mathrm{H} \quad \mathrm{Y}=\mathrm{H}$

$\underline{b} X=H \quad Y={ }^{2} \mathrm{H}$

$\underline{c} X={ }^{2} \mathrm{H} \quad Y=H$

$\mathrm{d} X={ }^{2} \mathrm{H} \quad \mathrm{Y}=2 \mathrm{H}$

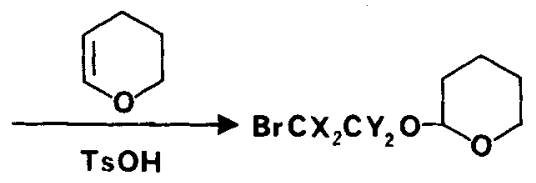

4

The next step in the reaction scheme involved a Sn2-type displacement of the bromide from the appropriately deuterated ethane derivative by the in situ - generated sodium salt of diethyl acetamidomalonate in either ethanol or ethanol-OD.(8) Hydrolysis and decarboxylation of the condensation product in either $6 \mathrm{~N} \mathrm{HCl}$ or DCl permitted the isolation of the desired deuterated lactone as depicted in Scheme 2.

The overall yield of the deuterated lactone in these three steps is only $45-52 \%$. However, only the lactonization step is poor, mainly due to the fact that in acidic aqueous ethanolic solutions homoserine lactone is in equilibrium with homoserine. Mudd (9) has demonstrated that when D,L-homoserine is dissolved in $6 \mathrm{~N} \mathrm{HCl}$ for $1 \mathrm{hr}$ at room temperature, an equilibrium mixture of lactone $(60 \%)$ and homoserine $(40 \%)$ is obtained. Armstrong (10) has also reported low yields $(41-44 \%)$ in the preparation of D- and L-homoserine lactone-HBr from D- and L-O-phenyl homoserine via treatment with $48 \% \mathrm{HBr}$.

Since the enzymes to be studied utilize only the L-homoserine derivative, it is not necessary to resolve the enantiomers. We have, however, resolved several of the target lactones by dissolving them in buffer solution $(\mathrm{pH}=8.5)$ and allowing them to stand for 1-2 hr, then treating the resulting mixture with D-amino acid oxidase and catalase using standard methods.(11) After separation of the amino acid from the keto 
<smiles>Br[14C]#[14C]C1CCCCO1</smiles>

4
1) $\mathrm{Na} \cdot \mathrm{CH}_{3} \mathrm{CH}_{2} \mathrm{OZ}$

2) $\mathrm{HC}\left(\mathrm{CO}_{2} \mathrm{C}_{2} \mathrm{H}_{5}\right)_{2} \mathrm{NHCOCH}_{3} \longrightarrow$

\section{$\underline{5}$}

$$
\begin{aligned}
& Z=2 H \\
& Z=2 H \\
& Z=2 H \\
& Z=H \\
& Z=H \\
& Z=H
\end{aligned}
$$

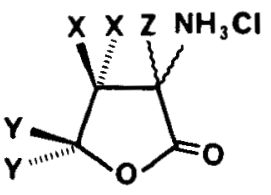

acid, one obtains optically pure homoserine which may be lactonized or derivatized directly.

The ${ }^{1} \mathrm{H}-\mathrm{nmr}$ spectra were measured at $270 \mathrm{MHz}$ without deuterium decoupling and the results are summarized in Table 1 along with the Dreiding models of two of the more stable conformations of the five-membered lactone ring system.

\section{EXPERIMENTAL}

Melting points were determined on a Mel-Temp apparatus and are uncorrected. All chemicals were obtained from Aldrich Chemical Co. and were used without further purification. Percent deuterium incorporations were determined from ${ }^{1} \mathrm{H}-\mathrm{nmr}$ spectral data. NMR spectra were obtained on an IBM WP-270 MHz NMR spectrometer. Anhydrous diethyl ether (Mallinckrodt) was used without further purification.

\section{2-Bromo[1,1-2 $\mathrm{H}_{2}$ ]ethanol $1 \mathrm{~b}$.}

Compound $1 \mathrm{~b}$ was prepared by a modification of the previously published procedure(6). A suspension of lithium aluminum deuteride (98.9 atom \% D) (1.25 g; $0.03 \mathrm{~mol})$ in dry diethyl ether $(150 \mathrm{~mL})$ was stirred at $-78^{\circ} \mathrm{C}$ for $30 \mathrm{~min}$. To a cooled, stirred suspension, anhydrous aluminium chloride ( $4.00 \mathrm{~g} ; 0.03 \mathrm{~mol}$ ) was added in small portions from a solid addition device in a manner that allowed the temperature of the stirred suspension to be maintained at $-75^{\circ} \mathrm{C}$. The mixture was then stirred for an additional 30 min at $-78^{\circ} \mathrm{C}$. To this suspension, ethyl bromoacetate $(5.0 \mathrm{~g} ; 0.03 \mathrm{~mol})$ in 
$50 \mathrm{~mL}$ of dry diethyl ether was added dropwise over a $30 \mathrm{~min}$ period from a constant pressure addition funnel. The resultant mixture was then stirred at $-78^{\circ} \mathrm{C}$ for an additional $2 \mathrm{hr}$ and then allowed to warm slowly to room temperature. Excess deuteride was destroyed by the addition of ethyl acetate $(5 \mathrm{~mL})$ followed by water $(5$ $\mathrm{mL}$ ). The ether solution was decanted and the aluminum salts were washed with ether $(3 \times 75 \mathrm{~mL})$. The combined diethyl ether extracts were dried $\left(\mathrm{Na}_{2} \mathrm{SO}_{4}\right)$, concentrated and distilled to give $2.2 \mathrm{~g} \mathrm{(58 \% )}$ of 2-bromo[1,1-2 $\mathrm{H}_{2}$ ]ethanol $1 \mathrm{~b}$ : bp $56-57^{\circ} \mathrm{C} / 20 \mathrm{~mm} \mathrm{Lit}$ (8) $65-68^{\circ} \mathrm{C} / 33 \mathrm{~mm}{ }^{1} \mathrm{H}-\mathrm{nmr}\left(\mathrm{CDCl}_{3}\right)$ d $2.52(\mathrm{~s}, 1 \mathrm{H}, \mathrm{OH}), 3.64\left(\mathrm{~s}, 2 \mathrm{H},-\mathrm{CH}_{2} \mathrm{Br}\right)$.

\section{2-Bromo $\left[2,2-2 \mathrm{H}_{2}\right]$ ethanol $1 \mathrm{C}$.}

Using the method described above, $8.45 \mathrm{~g}(0.05 \mathrm{~mol})$ of ethyl bromo-[2,2${ }^{2} \mathrm{H}_{2}$ lacetate $(6)$ and lithium aluminium hydride $(2.01 \mathrm{~g} ; 0.05 \mathrm{~mol})$-anhydrous aluminium chloride $(6.6 \mathrm{~g} ; 0.05 \mathrm{~mol})$ were reacted to give $3.40 \mathrm{~g}$ of $1 \mathrm{c}:$ bp $55-57^{\circ} \mathrm{C} / 20 \mathrm{~mm} 1 \mathrm{H}$ $\mathrm{nmr}\left(\mathrm{CDCl}_{3}\right)$ d $2.56(\mathrm{~s}, 1 \mathrm{H}, \mathrm{OH}), 3.85\left(\mathrm{~s}, 2 \mathrm{H},-\mathrm{CH}_{2} \mathrm{OH}\right)$.

\section{2-Bromo[1,1,2,2-2 $\left.\mathrm{H}_{4}\right]$ ethanol $1 \mathrm{~d}$.}

Compound 1d was prepared by the same procedure described for the preparation of 2-bromo[1,1-2 $\left.\mathrm{H}_{2}\right]$ ethanol 1b. Ethyl 2-bromo[2,2-2 $\left.\mathrm{H}_{2}\right]$ acetate $(8.45 \mathrm{~g}$; $0.05 \mathrm{~mol})$ and lithium aluminum deuteride $(2.01 \mathrm{~g} ; 0.05 \mathrm{~mol})$ and anhydrous aluminum chloride (6.6 g; $0.05 \mathrm{~mol}$ ) were reacted to give $3.35 \mathrm{~g}(52 \%)$ of 2-bromo[1,1,2,2${ }^{2} \mathrm{H}_{4}$ ]ethanol 1d; bp $56-57^{\circ} \mathrm{C} / 20 \mathrm{~mm}$.

\section{2-Bromo-1-(2'-tetrahydropyranyloxy)ethane $4 a$.}

The title compound was prepared by a modification of the method reported by Witiak et. al. (7) To a stirred solution of dihydropyran (2.02 g; $0.024 \mathrm{~mol})$ and a catalytic amount of $p$-toluenesulfonic acid $(\mathrm{TsOH})(15 \mathrm{mg})$ at $0^{\circ} \mathrm{C}$ was added 2bromoethanol $(3.0 \mathrm{~g} ; 0.02 \mathrm{~mol})$. The reaction mixture was stirred at room temperature for $2 \mathrm{hr}$. Distillation of the reaction mixture in the presence of solid $\mathrm{NaHCO}_{3}$ afforded $3.55 \mathrm{~g}\left(85 \%\right.$ ) of a colorless liquid: bp $63-64^{\circ} \mathrm{C} / 0.5 \mathrm{~mm}$ (Lit. (7) bp $67-68^{\circ} \mathrm{C} / 0.7 \mathrm{~mm}$ ).

\section{2-Bromo-[1,1-2 $\left.\mathrm{H}_{2}\right]-1-(2$ '-tetrahydropyranyloxy)ethane $4 \mathrm{~b}$.}

Dihydropyran (1.09 $\mathrm{g} ; 0.013 \mathrm{~mol})$ was added to $\left[1,1-2 \mathrm{H}_{2}\right]$-2-bromoethanol (1.5 
g, 0.012 mol) containing a catalytic amount of TsOH. Workup as de-scribed above gave a colorless liquid: bp $64-66^{\circ} \mathrm{C} / 0.5 \mathrm{~mm}$. ${ }^{1} \mathrm{H}-\mathrm{nmr}\left(\mathrm{CDCl}_{3}\right)$ d 1.3-1.9 (m, $6 \mathrm{H}, 3^{\prime}, 4$ ', 5'-CH$\left.{ }_{2}\right)$, 3.3-3.85 (m, $4 \mathrm{H}, 6$ '- $\mathrm{CH}_{2}$ and $\left.\mathrm{Br}^{-} \mathrm{CH}_{2}-\mathrm{C}^{2} \mathrm{H}_{2}-\right), 4.4$ (b.s., $1 \mathrm{H}, 2^{\prime}-\mathrm{H}$ ).

\section{2-Bromo-[2,2-2 $\left.\mathrm{H}_{2}\right]-1-(2$ '-tetrahydropyranyloxy)ethane $4 \mathrm{C}$.}

The tetrahydropyranylether from 2-bromo- $\left[2,2-{ }^{2} \mathrm{H}_{2}\right]$ ethanol was prepared by the procedure described above. The oil was isolated in $80 \%$ yield after vacuum distillation: bp $60-61^{\circ} \mathrm{C} / 0.2 \mathrm{~mm}$. 1 ${ }^{1} \mathrm{H}-\mathrm{nmr}\left(\mathrm{CDCl}_{3}\right)$ d 1.3-1.9 (m, $\left.6 \mathrm{H}, 3^{\prime}, 4^{\prime}, 5^{\prime}-\mathrm{CH}_{2}\right)$, 3.2$3.85\left(\mathrm{~m}, 4 \mathrm{H}, 6^{\prime}-\mathrm{CH}_{2}\right.$ and $\left.\mathrm{Br}-\mathrm{C}^{2} \mathrm{H}_{2}-\mathrm{CH}_{2}^{-}\right), 4.28$ (b.s., $\left.1 \mathrm{H}, 2^{\prime}-\mathrm{H}\right)$.

\section{2-Bromo- $\left[1,1,2,2-2 \mathrm{H}_{4}\right]-1-\left(2^{\prime}\right.$-tetrahydropyranyloxy)ethane $4 \mathrm{~d}$.}

The ether $4 d$ was prepared by the same method as the pyranylether $4 a$. The product was isolated by vacuum distillation as a clear oil: bp $63-64^{\circ} \mathrm{C} / 0.5 \mathrm{~mm}$ in a yield of $78 \%$. ${ }^{1} \mathrm{H}-\mathrm{nmr}\left(\mathrm{CDCl}_{3}\right)$ d 1.3-1.9 (m, $\left.6 \mathrm{H}, 3^{\prime}, 4^{\prime}, 5^{\prime}-\mathrm{CH}_{2}\right), 2.9-3.65\left(\mathrm{~m}, 2 \mathrm{H}, 6{ }^{\prime}-\mathrm{CH}_{2}\right)$, 4.2 (b.s., 1 H, 2'-H).

\section{D,L-[2-2H]Homoserine lactone hydrochloride $5 \mathbf{a}$.}

To a solution of $0.12 \mathrm{~g} \mathrm{(5} \mathrm{mg} \mathrm{atom)} \mathrm{of} \mathrm{sodium} \mathrm{in} \mathrm{C}_{2} \mathrm{H}_{2} \mathrm{OD}(5 \mathrm{~mL})$ was added, with stirring, diethyl acetamidomalonate $(1.08 \mathrm{~g} ; 5 \mathrm{mmol})$ and the mixture was heated under reflux for $0.5 \mathrm{hr}$ under a nitrogen atomosphere. After the suspension of diethyl sodium acetamidomalonate had cooled, 2-bromo-1-(2'-tetrahydropyranyloxy) ethane $(1.2 \mathrm{~g} ; 5.2 \mathrm{mmol}$ ) was added and the mixture was stirred at room temperature for $3 \mathrm{hr}$ and heated at reflux for $12 \mathrm{hr}$. After cooling to $25^{\circ} \mathrm{C}, 15 \mathrm{~mL}$ of DCl $(20 \% \mathrm{wt} / \mathrm{wt})$ was added and the solution heated at reflux for $24 \mathrm{hr}$. The majority of the $\mathrm{DCl}$ and $\mathrm{C}_{2} \mathrm{H}_{5} \mathrm{OD}$ was removed under water aspiration pressure. Water $(5 \mathrm{~mL})$ was added to the dark waxy residue and the aqueous portion of the solution was decanted and concentrated to $2 \mathrm{~mL}$. Absolute ethanol $(25 \mathrm{~mL})$ was added to this solution and the resulting mixture was evaporated under reduced pressure. This process was repeated twice and the resulting residue dried in vacuo at $100^{\circ} \mathrm{C}$. The semi-crystalline solid was dissolved in $25 \mathrm{~mL}$ of boiling absolute ethanol and filtered to remove any undissolved sodium bromide. The volume of the filtrate was reduced to $7 \mathrm{~mL}$ and left standing at $4^{\circ} \mathrm{C}$ overnight. The white crystalline product that separated was filtered and dried in vacuo 
to yield $52 \%$ of the title compound $(0.364 \mathrm{~g})$ with a $\mathrm{mp} 203-205^{\circ} \mathrm{C}$ (Lit. (12) $\mathrm{mp} 198$ $199.5^{\circ} \mathrm{C}$ for the nondeuterated analog). Compound $5 \mathrm{a}$ showed an incorporation of 99.0 atom \%of deuterium.

\section{D, L- $\left[2,4,4-2 \mathrm{H}_{3}\right]$ Homoserine lactone hydrochloride $5 \mathrm{~b}$.}

Compound $5 \mathrm{~b}$ was obtained from 2-Bromo-[1,1-2 $\left.\mathrm{H}_{2}\right]-1-(2$-tetrahydropyranyloxy)ethane $4 \mathrm{~b}(1.2 \mathrm{~g} ; 5.7 \mathrm{mmol})$ and diethyl acetamidomalonate $(1.09 \mathrm{~g} ; 5 \mathrm{mmol})$ by the same procedure described above. Recrystallization from absolute ethanol gave white crystals, $\mathrm{mp} 203-205^{\circ} \mathrm{C},(0.34 \mathrm{~g} ; 49 \%)$. The atom percent of deuterium in $5 \mathrm{~b}$ estimated from the integrated $\mathrm{nmr}$ spectrum was $98 \%$.

\section{D, L- $\left[2,3,3-2 \mathrm{H}_{3}\right]$ Homoserine lactone hydrochloride $5 \mathrm{c}$.}

By following the above procedure, $5 \mathrm{c}, \mathrm{mp} 202-204^{\circ} \mathrm{C}$ (absolute ethanol) was obtained in $49 \%$ yield from $(1.2 \mathrm{~g} ; 5.7 \mathrm{mmol})$ of $4 \mathrm{c}$. The isotopic purity of the compound $5 \mathrm{c}$ was determined by $\mathrm{nmr}$ to be $98.5 \%$.

\section{D,L-[3,3,4,4-2 $\left.\mathrm{H}_{4}\right]$ Homoserine lactone hydrochloride $5 \mathrm{~d}$.}

The title compound was prepared in a procedure analogous to that reported for 5a except that the non-deuterated ethanol was used as the solvent and the hydroylsis, decarboxylation, and deprotection were accomplished with non-deuterated hydrochloric acid to yield $0.33 \mathrm{~g}(47 \%)$ of a white solid with a $\mathrm{mp} 203-205^{\circ} \mathrm{C}$. The atom percent of deuterium in $\mathbf{5 d}$ obtained from the integrated $\mathrm{nmr}$ spectrum was $98.5 \%$.

\section{D,L-[4,4-2 $\left.\mathrm{H}_{2}\right]$ Homoserine lactone hydrochloride $5 e$.}

Lactone 5 e was prepared in the same manner as $\mathbf{5 d}$ from $\mathbf{4 b}$ in $46 \%$ yield with a $\mathrm{mp} 202-204^{\circ} \mathrm{C}$. The isotopic purity of the compound $5 e$ was determined by $\mathrm{nmr}$ to be $98.7 \%$.

\section{D, L- $\left[3,3-2 \mathrm{H}_{2}\right]$ Homoserine lactone hydrochloride $5 \mathrm{f}$.}

In an experiment similiair to that for $5 \mathrm{e}, 0.6 \mathrm{~g}$ of $4 \mathrm{c}$ was converted into $0.17 \mathrm{~g}$ $(51 \%)$ of $5 f, \mathrm{mp} 201-203^{\circ} \mathrm{C}$. Compound $5 f$ showed an incorporation of 98.5 atom $\%$ of deuterium. 
Table 1. ${ }^{1 H-n m r}$ Data On Homoserine Lactone Hydrochloride.

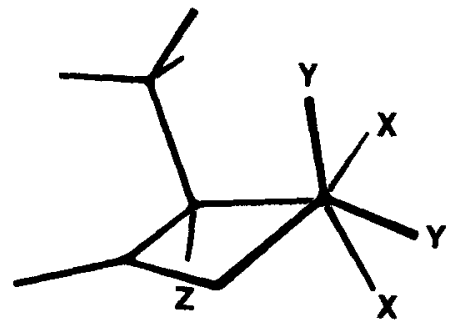

\begin{tabular}{|c|c|c|c|c|c|}
\hline Compd & $\mathrm{H}_{2}(\mathrm{Z})$ & $\mathrm{H}_{3}(\mathrm{X})$ & $H_{3}(X)$ & $\mathrm{H}_{4}(\mathrm{Y})$ & $\mathrm{H}_{4}(\mathrm{Y})$ \\
\hline $5 \mathbf{a}$ & .... & $2.56\left(q^{*}\right)$ & $2.29\left(q^{*}\right)$ & $\begin{array}{l}4.47\left(q^{*}\right) \\
J=8.8 \mathrm{~Hz}\end{array}$ & $4.28(\mathrm{~m})$ \\
\hline $5 b$ & $\cdots$ & $\begin{array}{l}2.54(d) \\
J=12.3 \mathrm{~Hz}\end{array}$ & $\begin{array}{l}2.27(d) \\
J=12.2 \mathrm{~Hz}\end{array}$ & --. & -.- \\
\hline $5 c$ & $\ldots$ & $\ldots$ & $\cdots$ & $\begin{array}{l}4.47(\mathrm{~d}) \\
\mathrm{J}=8.8 \mathrm{~Hz}\end{array}$ & $\begin{array}{l}4.28(d) \\
J=8.9 \mathrm{~Hz}\end{array}$ \\
\hline $5 d$ & 4.33 (s) & --- & $\cdots$ & $\cdots$ & $\cdots$ \\
\hline $5 e$ & $\begin{array}{l}4.33(d d) \\
J=11.3 \mathrm{~Hz} \\
J=8.9 \mathrm{~Hz}\end{array}$ & $\begin{array}{l}2.62(d d) \\
J=12.2 \mathrm{~Hz} \\
J=8.9 \mathrm{~Hz}\end{array}$ & $\begin{array}{l}2.38\left(t^{*}\right) \\
\mathrm{J}=11.8 \mathrm{~Hz}\end{array}$ & $\cdots$ & $\ldots$ \\
\hline $5 f$ & $4.33(s)$ & --- & $\cdots$ & $\begin{array}{l}4.45(d) \\
J=8.8 \mathrm{~Hz}\end{array}$ & $\begin{array}{l}4.28(d) \\
J=8.9 \mathrm{~Hz}\end{array}$ \\
\hline
\end{tabular}

\section{ACKNOWLEDGMENT}

This work was supported by U. S. Public Health Service Grant GM 30097. We are grateful to the U. S. P. H. S. and the College of Pharmacy for their contribution to the purchase of the IBM $270 \mathrm{MHz}$ NMR.

\section{REFERENCES}

1. Walsh, C. - In "Enzymatic Reaction Mechanisms", W. H. Freeman and Co., N. Y., 1979, pp. 823-827.

2. Kerr, D. and Flavin, M. - Biochem. Biophy. Res. Comm. 31: 124 (1968).

3. Flavin, M. and Kono, T. - J. Biol. Chem. 235: 1109-1111 (1960).

4. Chang, M. N. T. and Waish, C. T. - J. Am. Chem. Soc. 103: $4921-4917$ (1981). 
5. Chang, M. N. T. and Walsh, C. T. - J. Am. Chem. Soc. 102: $7370-7372$ (1980).

6. Hogg, J. L. and Schowen, R. L. - J. Pharm. Sci. 63: 1620-1623 (1974).

7. Witiak, D. T., Poochikian, G. K., Feller, D. R., Kenfield, N. A. and Neusman, H. A. I. J. Med. Chem. 18: $992-1000$ (1975).

8. Ramalingam, K. and Woodard, R. W. - J. Labelled Compounds XXI, 563-568 (1984).

9. Mudd, S. H. - J. Biol. Chem. 237: 87-92 (1959).

10. Armstrong, M. D. - J. Am. Chem. Soc. 71: 3399-3402 (1949).

11. Greenstein, J. P., Birnbaum, S. M. and Otey, C. M. - J. Biol. Chem. 204: 307-321 (1953).

12. Fillman, J. and Albertson, N. - J. Am. Chem. Soc. 70: 171-74 (1948). 